\author{
Andrey V. Kuklin' \\ Elena A. Bratukhina \\ Yulia 0. \\ Gorokhovitskaya
}

Article info:

Received 17.10.2020

Accepted 26.01.2021

UDC - 37.014.6

DOI - 10.24874/IJQR15.02-06

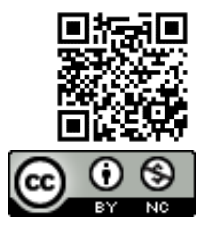

\section{QUALITY AS THE KEY LANDMARK OF EDUCATION MANAGEMENT IN THE REGIONAL ECONOMY}

Abstract: This paper aims to develop a new approach to management of education in the regional economy, which is oriented at quality. Originality of this research consists in considering quality as the key landmark of management of education in the regional economy. This ensures harmonization of non-commercial and commercial function of universities. It is proved - by the example of modern Russia - that quality should be the key landmark of management of education in the regional economy. It is determined that in 2020 quality of services of secondary vocational and higher education in Russia's regional economy has a secondary role, determinining the opportunities for employment of university graduates by $31.22 \%$ and having almost no influence on the level of their wages. The key factor of graduates' employment is the number and qualification of lecturers (48.75\%). The perspectives of increase of quality of services of secondary vocational and higher education in Russia's regional economy are connected to transition to the practice-oriented model of education, active use of the network form of education, wide professional and public accreditation of educational programs by employers, and upgrade of equipment and equipment of universities. For this we offer applied recommendations, which are based on expansion of the use of the leading technologies according to the federal project of digital education, which is successfully implemented in Russia's regions and is oriented for the period until 2024.

Keywords: Quality; Key landmark; Education management; Higher education; Universities; Regional economy; Regions of Russia; Quality management.

\section{Introduction}

Quality of education poses large interest for all subjects of the educational services market in a region. This is seen most vividly in the sphere of secondary vocational and higher education, for quality of school education is regulated by national and international educational standards, while further education is moderately standardized and shows sufficiently high flexibility even in countries where state-funded educational establishments dominate in the sphere of secondary vocational and higher education. Let us consider a view of quality from the positions of all interested parties by the example of Russia as a country with high level of education and vivid regionalization

${ }^{1}$ Corresponding author: Andrey V. Kuklin

Email: $\underline{\text { av kuklin@ vyatsu.ru }}$ 
of economy.

Consumers try to increase their competitiveness in the labor market by means of education. Graduates with their first secondary vocational or higher education are interested in working in their specialty. According to the materials of the Federal State Statistics Service (2020), coefficient of tension in the labor market in Russia constitutes 2.7 - i.e., there are 27 unemployed per 1 vacancy. According to the National Research University "Higher School of Economics" (2020), employment of economically active population with just secondary education is $29.2 \%$ in Russia. Employment of population with secondary vocational education is $72 \%$, and with higher education $-81.5 \%$.

Only $60.3 \%$ of graduates with secondary vocational education work in their specialty; among graduates with higher education this number is $68.9 \%$. Therefore, the level of education in Russia largely determines the position of an employee in the labor market and the possibilities of his successful employment. Specialists with work experience usually take advanced training courses and try to build their career. A lot of government-owned and private enterprises of Russia set high requirements to education of employees with top positions at all levels of the corporate management system.

Public authorities in regions are interested in increase and realization of human potential for increasing effectiveness and competitiveness of the region's economy. As human resources in the knowledge economy are the decisive factor of production and the criterion that determines the region's (and country's) position in various rankings, quality of education is very important for state regulators of the educational services market in regions. Entrepreneurs - as indirect consumers of educational services through the labor market - are interested in overcoming the deficit of human resources for increasing business activities. At the region's scale, this ensures the increase of investment attractiveness and acceleration of economic growth.

However, despite the importance of quality, the existing practices of education management in the regional economy take it to the background. In the practice of developed countries (e.g., the UK and the USA), where private universities dominate, education management is oriented, on the one hand, at maximization of the scientific achievements of universities, and, on the other hand, at provision of prestige of education (strengthening of brand). In the practice of developing countries (e.g., Russia), where state universities dominate, education management is oriented at increase of effectiveness of universities' activities for the purpose of saving budget assets.

It should be emphasized that neither high research activity of a university, nor strong brand or high effectiveness guarantees high quality of the provided educational services. The contradiction of preferences of the interested parties and practices of education management is the scientific and practical problem of modern regions. For solving this contradiction, it is expedient to develop a new approach to management of education in the regional economy, which is oriented at quality.

Originality of this research consists in considering quality as the key landmark of management of education in the regional economy. This ensures harmonization of non-commercial and commercial function of universities. The developed new approach oriented at quality - to education management in the regional economy stimulates generation of public benefits by universities through development of region's human potential (non-commercial function) and execution of university's duties as per contract on education before the state (in case of state-financed education) or students' duties (in case of paid education), which are connected not only to provision of a diploma but, what's more important, development of 
competencies (formation of knowledge and skills) with students.

This allows overcoming the lack of practice of education management in the regional economy, which is presented in the market economy, consisting in prevailing of the commercial function in the universities' activities. Striving to maximize the commercial effectiveness, universities have been paying less attention to quality in recent decades. The transition to purely noncommercial activities cannot be achieved by modern universities due to the market relations in the system of post-secondary education and limited capabilities of state in financing of universities. The new approach allows universities reaching high commercial effectiveness and competitiveness by means of noncommercial activities on provision high quality of provided educational services.

This paper has the following structure. Introduction is followed by literature overview and gap analysis. Then, materials and methods of the research are given. Then, research results are provided, which include the following: 1) determining the role and factors of services' quality of secondary vocational and higher education in Russia's regional economy; 2) determining the perspectives of increasing quality of services of secondary vocational and higher education in Russia's regional economy; 3) developing recommendations on management of quality of education in the regional economy based on digital technologies. After this, the obtained results are discussed and treated qualitatively from the positions of the experience of education management in the regional economy of modern Russia. In the end, conclusions contain the key notes of the research.

\section{Literature Review}

Significance of the non-profit function of universities, consisting in training of personnel and formation and development of economy's human potential, in particular at the region's level is emphasized in the works of the following scholars. Kennedy and Birch (2020) perform a thematic study from the positions of public management and came to a conclusion that a significant direction of higher education management is support for implementation of the social services programs - creation of non-commercial benefits on training of personnel.

Anis and Islam (2019) point out the toppriority tasks and critical factors of success for provision of high-quality education (by the example of private universities in Malaysia). Altınay et al. (2019) study the processes and technologies of the systems of knowledge management in open and remote educational establishments of higher education. Jodoin (2020) deems it necessary to stimulate language education for sustainable development (proved by the example of Japanese higher education). Forsyth (2019) dwells on the concept of good university, looking for answers to the question what universities do and why now is the time for radical changes.

Eldegwy et al. (2018) performs an empirical study of the value of the brand of university's social improvements and thinks that an important feature of university's bran is its "communicativeness" (presence in mass media, openness for criticism, and involvement of interested parties). Bamber and Elezi (2020) notes that organizational culture of a university has a decisive role for formation and increase of quality of the provided educational services. Alexander and Manolchev (2020) point out the uncertainty of the system of higher education and note the surprising similarities between the future university (perspectives of its development in the current form) and university of the future (a new form of organization and management of university).

The scientific treatment of quality of services of secondary vocational and higher education is given in a lot of published 
works. Sahney (2019) and Roshani et al. (2019) study the structure of quality in education by using the interpretative structural modeling. Hauptman and Komotar (2020) have a scientific discourse on quality and management of quality in higher education from the point of view of the global ranking of universities. Felce (2019) provide applied recommendations for managing the quality of higher education with involvement of students.

Wilson (2019) points out that feedback with lecturers is the key to supporting quality in education of adults (performs a thematic study of a private organization of higher education in New Zealand). Gerged and Elheddad (2020) think that national management could influence the quality of education (proved by the example of Western Europe). Pleśniarska (2019) performs a monitoring of progress of provision of services of higher education from the positions of quality in the European Union and substantiates the strategic frameworks and goals.

Ashraf (2019) notes the influence of the labor conditions and keeping lecturers on quality of education in private universities (shown by the example of Bangladesh). Serbina (2015) deems it expedient to develop quality in the context of the European model of quality of education CQAF (substantiated by the example of training of veterinarians in Russia). Vijay (2013) considers evaluating of student ranking as a measure of quality management of higher education = an institutional study with the use of the Six Sigma Methodology (shown by the example of India).

Domination of commercial landmarks in the modern practice of education management in the regional economy is noted in the following works. Watson and McGowan (2019) deem it necessary to reconsider the entrepreneurial training, which is based on competition, in higher educational establishments and think that universities have to use the models of interaction based on information on effectiveness. Matlay (2018) presents a new view at entrepreneurial activities of universities. Wright and Horta (2018) note the participation of higher education in the universal systems of higher education with a high level of income as the survival in a society of risk.

Duan (2019) notes the necessity for using analysis of data coverage and analysis of strategic groups of measuring university's effectiveness (substantiated and approbated by the example of Australian universities). Rebelatto et al. (2019) studies the measures on increasing energy efficiency and their contribution to Goal 7 in the sphere of sustainable development (proved by the example of Brazilian universities). Günay and Dulupçu (2019) offer a methodology of measuring financial effectiveness and efficiency of state universities with the use of non-parametric methods (shown by the example of Turkish universities. Lombardi et al. (2019) study the strategic foundations of functioning and development of entrepreneurial universities (by the example of universities of Bari).

New and expanded opportunities for monitoring and provision of high quality of services of secondary vocational and higher education, which open in the conditions of the digital economy and Industry 4.0 due to implementation of smart technologies into the educational practice of universities and the practice of state and public control of their activities, are studied in the works Alpidovskaya and Popkova (2019), Inshakova and Bogoviz (2020), Popkova and Sergi (2020), Popkova (2017), Popkova (2019), Popkova (2020), Popkova et al. (2020), Popkova et al. (2017), Popkova and Sergi (2018), Popkova and Sergi (2019), Popkova et al (2019), Ragulina (2019), Savelyeva et al (2019), Shahin (2019), Shulus et al. (2020), Sozinova (2019), Sozinova et al (2019), and Stolyarov et al. (2020). 
Goryachikh et al. (2019) offer the methodological and practical recommendations for audit of digital personnel training for the regional economy in the conditions of Industry 4.0. Gerasimova et al. (2019) describes new state standards of higher education for training of digital personnel in the conditions of Industry 4.0. Bratukhina et al. (2020) offer the goals for application and new tools of marketing management of education quality in the process of university's reorganization in Industry 4.0. Sozinova (2018a), Sozinova (2018b), Sozinova et al (2017a), and Sozinova et al (2017b) study the processes of organization in view of quality management.

The performed literature review shows the theoretical and methodological aspects of measuring and evaluation of quality of the services of secondary vocational and higher education are sufficiently studied in the existing publications. There are also solid proofs of significance of quality in the universities' activities. However, the implemented practical approach to education management in the regional economy pays insufficient attention to quality and thus requires certain correction.

Deficit of scientific research on management of education quality in the regional economy is a gap in the system of accumulated knowledge. For overcoming this gap, main attention is paid to the managerial aspect of provision of high quality of secondary vocational and higher education in the regional economy.

\section{Materials and methodology}

This research is performed by the example of modern Russia - thus, its methodology is built on the basis of available information and empirical materials. The most precise (qualitative), full (for all regions and federal districts), detailed, and correct (reliable) statistical information on quality of services of secondary vocational and higher education in Russia could be found in the information and analytical materials of monitoring of quality of personnel training. The monitoring if conducted by the Ministry of Science and Higher Education of the Russian Federation (2020) annually; the most recent version is the 2019 version.

Among the indicators that are found in these information and analytical materials, quality of services of secondary vocational and higher education is reflected by share of graduates who find a job during the first year after graduation and graduates' average wages/region's average wages ratio. These indicators show that quality of education determines competitiveness of employees in the labor market in a region and their opportunities for employment and career building, as well as their value (cost) in the system of region's human resources. Systematization of other information and analytical materials of the monitoring allows distinguishing four groups of factors that potentially influence the quality of services of secondary vocational and higher education in a region,

Firstly, progressiveness of educational programs that are used by the region's universities. Its indicators are share of students using the practice-oriented model of education, share of educational programs that are implemented with the use of the network form, and share of educational programs that passed professional and public accreditation by employers and their unions. Secondly, the level of graduates' knowledge. Its indicator is average score of graduates during state final examination.

Thirdly, technical equipment of a university. Its indicators are coefficient of upgrade of equipment and equipment that are used during implementation of educational programs and share of educational and production workshops equipped with the modern material and technical base. Fourthly, number and qualification of lecturers. Its indicators are share of university employees with expert certificate WorldSkills, share of lecturers that have a 
part-time job at the profile companies, and number of lecturers per 100 students (university's academic staff).

For covering the whole regional economy of Russia and obtaining the most detailed and correct results, this research is performed by the example of large territories - federal districts that include regions. The data on them are shown in Table 1.

Table 1. Quality of services of secondary vocational and higher education in the regional economy of Russia in 2020.

\begin{tabular}{|c|c|c|c|c|c|c|c|c|c|c|}
\hline $\begin{array}{c}\text { No. of } \\
\text { indicator* }\end{array}$ & Indicator & $\begin{array}{l}\text { \& } \\
\text { है } \\
\text { ह }\end{array}$ & 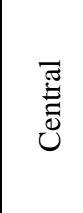 & 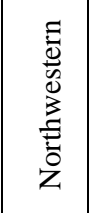 & $\frac{\pi}{00}$ & 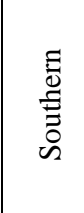 & 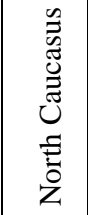 & $\frac{\infty}{\sqrt[T]{5}}$ & 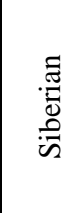 & 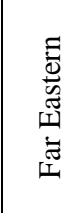 \\
\hline 1.11 & $\begin{array}{l}\text { Share of students using the } \\
\text { practice-oriented model of } \\
\text { education, } \%\end{array}$ & $\mathrm{X} 1$ & 6.63 & 2.29 & 2.58 & 0.92 & 1.28 & 2.31 & 2.94 & 1.31 \\
\hline 1.13 & $\begin{array}{l}\text { hare of educational programs tha } \\
\text { are implemented with the use of } \\
\text { the network form, } \%\end{array}$ & $\mathrm{x}_{2}$ & 20.20 & 10.04 & 13.83 & 5.77 & 5.74 & 7.00 & 11.16 & 5.74 \\
\hline 1.14 & $\begin{array}{c}\text { hare of educational programs tha } \\
\text { passed professional and public } \\
\text { accreditation by employers and } \\
\text { their unions, } \%\end{array}$ & $\mathrm{X} 3$ & 15.54 & 11.39 & 16.35 & 13.61 & 12.79 & 7.80 & 14.65 & 27.88 \\
\hline 3.7 & $\begin{array}{l}\text { Average score of graduates during } \\
\text { state final examination, points } 1- \\
100\end{array}$ & $\mathrm{X}_{4}$ & 49.40 & 28.63 & 29.46 & 4.46 & 36.69 & 40.06 & 33.58 & 55.27 \\
\hline 4.5 & $\begin{array}{c}\text { Coefficient of upgrade of } \\
\text { quipment and equipment that are } \\
\text { used during implementation of } \\
\text { educational programs, } \%\end{array}$ & $\mathrm{X} 5$ & 8.36 & 5.11 & 6.88 & 6.90 & 6.28 & 7.95 & 7.66 & 13.54 \\
\hline 4.10 & $\begin{array}{c}\text { Share of educational and } \\
\text { production workshops equipped } \\
\text { with the modern material and } \\
\text { technical base, } \%\end{array}$ & $\mathrm{X}_{6}$ & 26.80 & 18.07 & 17.73 & 18.51 & 21.30 & 23.52 & 17.92 & 23.91 \\
\hline 6.1 & $\begin{array}{c}\text { Share of university employees } \\
\text { with expert certificate } \\
\text { WorldSkills, \% } \\
\end{array}$ & $\mathrm{X}_{7}$ & 0.99 & 0.79 & 0.68 & 0.73 & 0.26 & 0.60 & 0.69 & 0.53 \\
\hline 6.2 & $\begin{array}{c}\text { Share of lecturers that have a part- } \\
\text { ime job at the relevant companies } \\
\%\end{array}$ & $\mathrm{X}_{8}$ & 1.41 & 1.05 & 0.79 & 0.88 & 1.15 & 1.90 & 1.06 & 1.32 \\
\hline 6.8 & $\begin{array}{c}\text { Number of lecturers per } 100 \\
\text { students }\end{array}$ & $\mathrm{X} 9$ & 3.92 & 3.91 & 3.41 & 3.22 & 2.81 & 2.92 & 3.29 & 2.95 \\
\hline 7.1 & $\begin{array}{c}\text { Share of graduates who find a job } \\
\text { during the first year after } \\
\text { graduation, } \%\end{array}$ & $\mathrm{y}_{1}$ & 64.42 & 67.62 & 64.45 & 56.19 & 41.36 & 66.36 & 61.65 & 63.73 \\
\hline 7.2 & $\begin{array}{c}\text { Graduates' average } \\
\text { wages/region's average wages } \\
\text { ratio, } \%\end{array}$ & $\mathrm{y}_{2}$ & 71.12 & 69.25 & 77.62 & 75.18 & 87.19 & 69.36 & 74.00 & 76.36 \\
\hline
\end{tabular}

*Sequential number of indictor in the materials of the monitoring.

Source: compiled by the authors based on materials of the Ministry of Science and Higher Education of the Russian Federation (2020). 
Correlation analysis is used for determining the role and factors of quality of services of secondary vocational and higher education in Russia's regional economy. Coefficients of cross-correlation between the indicators of quality and the factors that potentially influence them are calculated. As the higher the indicators' values the better, positive correlation is treated positively. The higher the value of the cross-correlation coefficient, the stronger the connection between the indicators.

Regression analysis is used for determining the perspectives of increasing the quality of services of secondary vocational and higher education in Russia's regional economy. Models of multiple linear regression dependence of each indicator of quality (separately) on the totality of the selected indicators are compiled. Simplex method is used for automatic determination of the combination of factors at which maximum growth of both indicators of quality in in Russia's regional economy is achieved.

\section{Results}

\subsection{The role and factors of quality of services of secondary vocational and higher education in Russia's the regional economy}

For determining the general role and key factors of quality of the services of secondary vocational and higher education in Russia's regional economy, let us consider the results of analysis (Figures 1 and 2).

Correlation with share of employed graduates

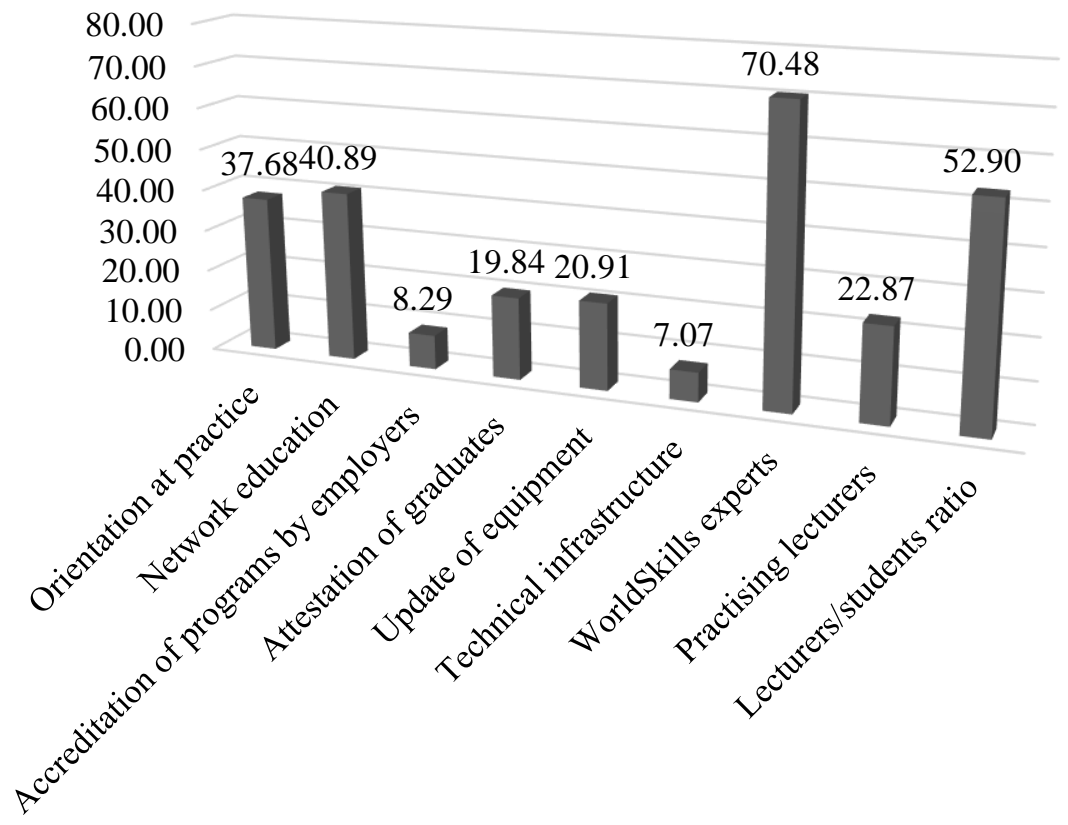

Figure 1. Cross-correlation between share of employed graduates and the factors of quality of education in Russia's regions in 2020, \%.

Source: calculated and compiled by the authors. 
Based on Figure 1, the highest correlation of share of graduates who found a job during the first year after graduation is with share of university's employees with a WorldSkills expert certificate (regions of Russia, 2020) $70.48 \%$.

Also, a rather significant factor is number of lecturers per 100 students (52.90\%). Moderate positive influence on quality of services of secondary vocational and higher education from the positions of stimulating graduates' employment in in Russia's regions in 2020 is performed only by share of students using the practice-oriented model of education (37.68\%), share of educational programs that are implemented with the use of the network form (40.89\%), average score of graduates during state final examination $(19.84 \%)$, coefficient of upgrade of equipment and equipment that are used during implementation of educational programs $(20.91 \%)$, and share of lecturers that have a part-time job at the profile companies $(22.87 \%)$.

Positive, but weak, influence on graduates' employment in 2020 is performed by share of educational programs that passed professional and public accreditation by employers and their unions (8.29\%), and share of educational and production workshops equipped with the modern material and technical base (7.07\%).

Correlation with level of graduates' wages

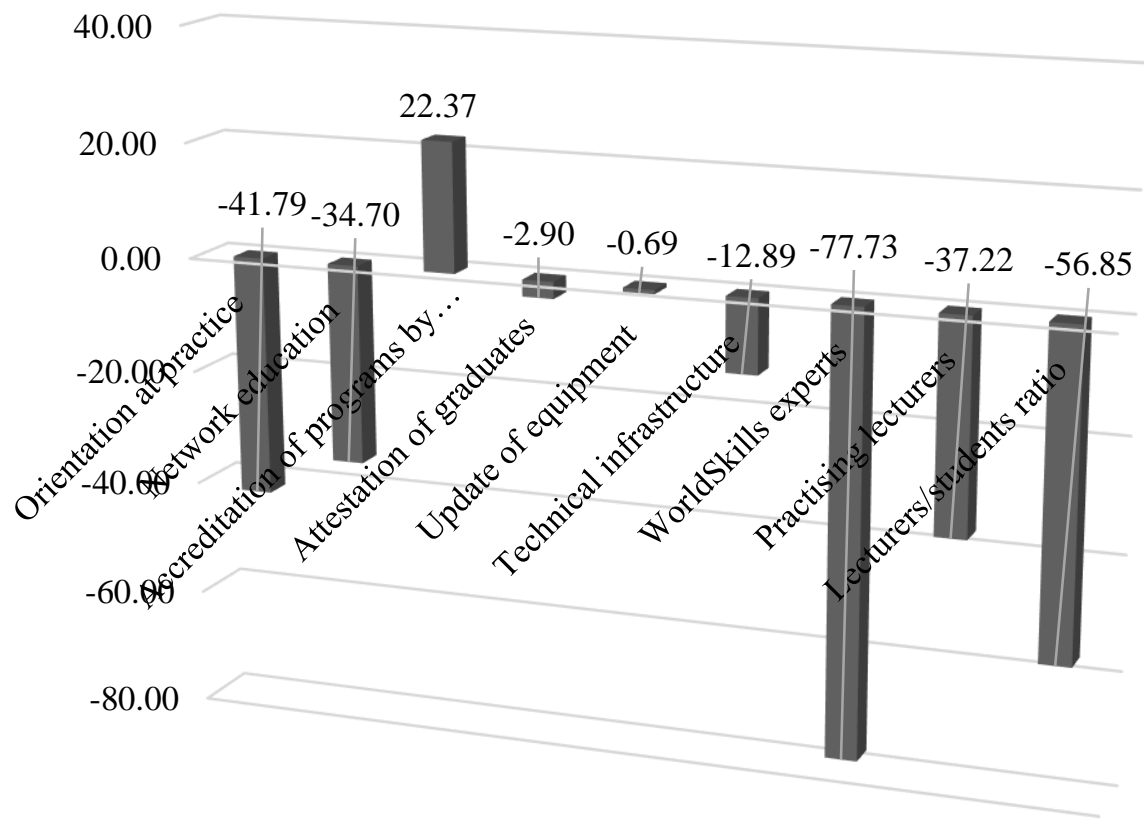

Figure 2. Cross correlation between the level of graduates' wages and the factors of quality of education in Russia's regions in $2020, \%$.

Source: calculated and compiled by the authors

Based on Figure 1, the highest correlation of average wages of graduates/average wages in region ratio in Russia's regions in 2020 is with share of educational program that passed professional and public accreditation by employers and their unions $(22.37 \%)$. This is the only factor that positively influences the quality of services of 
secondary vocational and higher education in Russia's regions from the positions of the level of their wages. Other factors negatively influence this manifestation of quality of education.

The largest negative influence on the level of wages of graduates of universities in Russia's regions in 2020 is performed by share of university employees with expert certificate WorldSkills $(-77.73 \%)$ and number of lecturers per 100 students $(-56.85 \%)$. A vivid influence on this component of quality of education is performed by share of students using the practice-oriented model of education $(-41.79 \%)$, share of educational programs that are implemented with the use of the network form $(-34.70 \%)$, average score of graduates during state final examination $(-2.90 \%)$, coefficient of upgrade of equipment and equipment that are used during implementation of educational programs ($0.69 \%$ ), share of educational and production workshops equipped with the modern material and technical base $(-0.69 \%)$, and share of lecturers that have a part-time job at the profile companies $(-37.22 \%)$.

To form a systemic vision of the influence of the selected factors on quality of services of secondary vocational and higher education in Russia's regional economy in 2020, let us use the averaged results of the correlation analysis (Figure 3).

Components of education quality as the factors of employment and wages

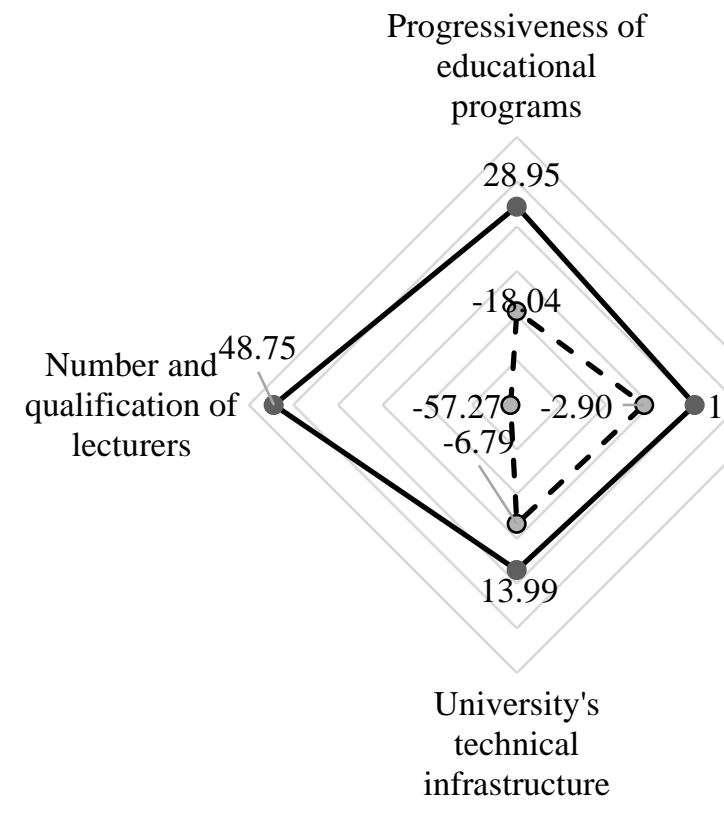

- Correlation with share of employed graduates

- o - Correlation with level of graduates' wages

\section{General connection between quality of education, employment, and wages}

Figure 3. Averaged correlation between the indicators and the factors of education quality in

Russia's regions in 2020, \%.

Source: calculated and compiled by the authors 
As shown in Figure 3, the key group of factors that strongly influences the quality of education in the aspect of employment of graduates in Russia's regional economy in 2020 is number and qualification of lecturers $(48.75 \%)$. Other groups of factors are also rather significant and positively influence employment. Average correlation of employment of graduates with progressiveness of educational programs constitutes $28.95 \%$, with level of graduates' knowledge - $19.84 \%$, and with technical infrastructure of universities $-13.99 \%$.

Level of graduates' wages does not depend on quality of services of secondary vocational and higher education, as it shows negative correlation with all groups of the studied factors. The general connection between graduates' employment and the factors of quality of services of secondary vocational and higher education constitutes $31.22 \%$.

Thus, in Russia's regional economy, quality has a secondary (moderately significant) role in formation of personnel potential of regions and competitiveness of universities' graduates in the labor market, determining the opportunities of their employment by $31.22 \%$ and has small influence on the level of their wages. This is probably connected to low values of the factors of quality.

For example, share of students using the practice-oriented model of education constitutes $2.53 \%$ on average - i.e., it is very small. Similarly, share of university employees with WorldSkills expert constitutes $0.66 \%$ on average, and share of lecturers that have a part-time job at the profile companies $-1.20 \%$. This emphasizes the necessity for improving the existing practice of managing the quality of education in Russia's regional economy.

\subsection{Perspectives of increase of quality of services of secondary vocational and higher education in Russia's regional economy}

For determining the perspectives of increasing the quality of services of secondary vocational and higher education in Russia's regional economy, let us use the results of the regression analysis from Table 1 , which are expressed in the following models of multiple linear regression:

$$
\begin{aligned}
- & \mathrm{y}_{1}=-40.40-11.24 * \mathrm{x}_{1}+3.23 * \mathrm{x}_{2-} \\
& 3.16^{*} \mathrm{x}_{3}+0.17 * \mathrm{x}_{4}-9.08^{*} \mathrm{x}_{5}{ }^{-} \\
& 0.84 * \mathrm{x}_{6}+0 * \mathrm{x}_{7}+0^{*} \mathrm{x}_{8}+25.93 * \mathrm{x}_{9} . \\
- & \mathrm{y}_{2}=133.20+2.18 * \mathrm{x}_{1}{ }^{-} \\
& 0.34 * \mathrm{x}_{2}+1.98 * \mathrm{x}_{3}+0^{*} \mathrm{x}_{4}- \\
& 5.51 * \mathrm{x}_{5}+0.65^{*} \mathrm{x}_{6}+0^{*} \mathrm{x}_{7}+0^{*} \mathrm{x}_{8}-18.36 * \mathrm{x}_{9} .
\end{aligned}
$$

The compiled regression models show precise quantitative dependencies of quality indicators - employment and level of graduates' employment - in Russia's regional economy in 2020 on the factors that influence quality. Based on the established dependencies, simplex method is used for determining target values of factor variables for systemic optimization (maximization) of the values of resulting variables (indicators of quality).

The target values are oriented at the period until 2024, as, on the one hand, this is a sufficient period of time (3-4 years) for achieving them, and, on the other hand, a rather remote period, which allows building forecasts (establishing target values for a longer period entails lower probability of their achievement). The received results are shown in Table 2.

If this optimal combination of the factors of education management in Russia's regional economy is reached until 2024, share of graduates who find a job during the first year after graduation will equal $97.94 \%$ and graduates' average wages/region's average wages ratio $-100.08 \%$. It should be noted that university graduates' average wages in Russia's regional economy constitutes $75.01 \%$ of average wages. This is due to 
insufficiency of applied competencies with university graduates and a low level of wages of young specialists because of small experience of work.

The small share of graduates who find a job during the first year after graduation ( $60.72 \%$ on average) is due to high tension in the Russian labor market (the number of the unemployed is much higher than the number of vacancies). Growth of indicators of quality will be very high $-61.29 \%$ for employment and $33.42 \%$ for graduates' wages. The target growth of the factors of education quality in Russia's regions in the period until 2024 is shown in Figure 4.

Table 2. Perspectives of increasing the quality of education in Russia's regional economy in the period until 2024.

\begin{tabular}{|c|c|c|c|}
\hline Variable & Average value in 2020 & Target value in 2024 & $\begin{array}{c}\text { Growth in 2024 as compared to } \\
2020, \%\end{array}$ \\
\hline $\mathrm{x}_{1}$ & 2.53 & 15.09 & 495.85 \\
\hline $\mathrm{x}_{2}$ & 9.93 & 75.00 & 654.91 \\
\hline $\mathrm{x}_{3}$ & 15.00 & 26.40 & 75.98 \\
\hline $\mathrm{x}_{4}$ & 34.69 & 34.72 & 0.08 \\
\hline $\mathrm{x}_{5}$ & 7.83 & 8.30 & 5.93 \\
\hline $\mathrm{x}_{6}$ & 20.97 & 20.97 & 0.00 \\
\hline $\mathrm{x}_{7}$ & 0.66 & 0.66 & 0.19 \\
\hline $\mathrm{x}_{8}$ & 1.19 & 1.20 & 0.42 \\
\hline $\mathrm{x}_{9}$ & 3.30 & 3.30 & -0.11 \\
\hline $\mathrm{y}_{1}$ & 60.72 & 97.94 & 61.29 \\
\hline $\mathrm{y}_{2}$ & 75.01 & 100.08 & 33.42 \\
\hline
\end{tabular}

Source: calculated and compiled by the authors.

\section{Orientation at practice}

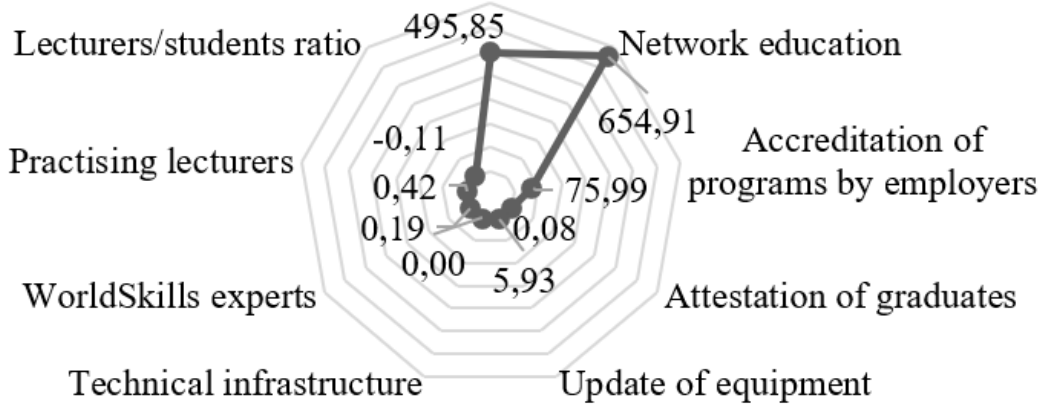

Figure 4. Target growth of the factors of education quality in Russia's regions in the period until 2024, \%

Source: calculated and compiled by the authors.

As shown in Figure 4, the highest target growth among the considered factors by 2024 has to be reached for share of students using the practice-oriented model of education (it is expected to grow 4.95 times), share of educational programs that are implemented with the use of the network form (it is expected to grow 6.54 times), share of educational program that passed professional and public accreditation by employers and their associations (it is expected to grow by $75.99 \%$ ), and 
coefficient of update of machines and equipment that are used during implementation of educational programs (it is expected to grow by $5.93 \%$ ).

\subsection{Recommendations on management of education quality in the regional economy based on digital technologies: practical implications}

The key initiative in the sphere of management of education quality in Russia's regional economy, which has been implemented in recent years and will be implemented in the period until 2024, is transition to digital education - EdTech. Digital education is one of the federal projects of the program "Digital economy of the Russian Federation", which was started in 2017.

Improvement of management of education quality in Russia has to be based on this program, for it provides wide opportunities for modernizing the existing practice and provides sufficient finances for this. According to Table 2 and Figure 4, conditions for increasing the quality of education in Russia's regional economy until 2024 are formulated, and recommendations for observing these conditions based on digital technologies in the interested of improvement of quality management are given (Table 3).

Table 3. Improvement of management of education quality in Russia's regional economy based on digital technologies.

\begin{tabular}{|c|c|}
\hline Condition of increase of education quality & $\begin{array}{c}\text { Fulfillment of the condition based on digital } \\
\text { technologies }\end{array}$ \\
\hline Transition to the practice-oriented model of education & creation of virtual training laboratories \\
\hline Active use of the network form of education & $\begin{array}{c}\text { organization of remote educational courses by network } \\
\text { universities }\end{array}$ \\
\hline $\begin{array}{c}\text { Professional and public accreditation of educational } \\
\text { programs by employers }\end{array}$ & $\begin{array}{c}\text { digital exchange of knowledge and information, digital } \\
\text { monitoring of educational programs }\end{array}$ \\
\hline Update of machines and equipment by universities & implementation of "smart" technologies into education \\
\hline
\end{tabular}

Source: developed and compiled by the authors.

As shown in Table 3, the first condition of increase of education quality in Russia's regional economy in the period until 2024 consists in transition to a practice-oriented model of education. Creation of training laboratories in universities is complicated, because, firstly, each enterprise's activities are specific and, secondly, production technologies and equipment are updated annually, and universities are behind the technological progress, while obsolete equipment does not allow developing applied competencies.

Multiple attempts at organization of practical training at enterprises were not successful, for enterprises' employees (tutors) are not interested in training students. This problem could be solved by creating virtual training laboratories-simulators. They will allow reproducing equipment and technologies of enterprises in 3D and using them in universities. A lot of models will be available. For this, universities will require technologies of virtual reality and agreements on cooperation with enterprises, which most Russian universities already have.

The second condition is active use of the network form of education. A wide network of universities has formed in Russia's regions in recent years. However, their cooperation is mostly in the methodological and scientific spheres. For developing a network cooperation of universities in the educational process, we offer organization of remote educational courses by network universities. This will allow for optimization of universities' organizational structure, and only the specialized chairs will remain. Nonspecialized disciplines will be taught by 
partner universities. This will allow students to receive high-quality educational services in all disciplines and to develop all necessary competencies.

The third condition envisages wide professional and public accreditation of educational programs by employed. As of now, this accreditation is difficult because the educational programs are not available for wide groups of people, which envisages a complex procedure of their transfer to employers. In order to overcome this barrier, we recommend the digital exchange of knowledge and information between universities and enterprises of a region and the digital monitoring of the educational programs by employers. At web-sites, which are created by universities, employers can create personal profiles and thus get access to educational programs and evaluate them and post comments in a convenient form.

The fourth condition is update of machines and equipment of universities. Instead of expansion of the computer network, it is recommended to implement smart technologies into education. Smart technologies will allow automatizing the evaluation of students' knowledge, increasing its speed, precision, and objectivity. The interactive educational process will allow students to better master the educational material. Big data and AI will allow involving students in scientific research, developing their creative (innovative) competencies, and stimulating successful preparation of graduation thesis.

\section{Discussion}

As is shown by experience of modern Russia, transition from the planned economy to the market economy and the high level of regionalization will lead to formation of a unique model of education. The specific features of the Russian model of secondary vocational and higher education are as follows:
- creation of flagship universities and national research institutes in most regions, which will unify a range of specialized universities. Enlargement of universities will guarantee full observation of federal state educational standards;

- Networkization of universities, with a lot of branches of a university, and developed partnership relations with a range of universities from other regions;

- Stimulation of continuation of training. A lot of training colleges are unified with universities. This allows graduates with secondary vocational education to perform an easier transfer to the next level for obtaining higher education.

These specific features create favorable conditions for implementing the authors' recommendations for improvement of the practice of education management in Russia's regional economy. However, a serious drawback is the high level of dependence of state-funded universities on budget financing - which hinders marketization of their activities. A barrier on the path of solving this problem is, firstly, the pricing inaccessibility of the higher education services for wide groups of population, and, secondly, a small perspective of return of investments in education.

The solution for overcoming these barriers is beyond the limits of the market of educational services - in the labor market and in the practice of increasing population's living standard. These barriers will probably remain until 2024. That's why quality of the services of secondary vocational and higher education will be formed under the influence of not the market (competition) but the regulatory mechanism. Perspectives of improving the regulatory mechanism are connected to organization of the digital public monitoring of education quality in Russia's regions, which agrees with the 
offered recommendations and could be implemented within the federal project of digital education.

\section{Conclusion}

Thus, it is proved - by the example of modern Russia - that quality should be the key landmark of management of education in the regional economy. In 2020, quality of services of secondary vocational and higher education in Russia's regional economy has a secondary role in Russia's regional economy, determining the opportunities of employment of university graduates by $31.22 \%$ and having almost no influence on the level of their wages. The key factor of graduates' employment is number and qualification of lecturers (48.75\%). Progressiveness of educational programs determines the opportunities for employment of university graduates by $28.95 \%$, the level of knowledge - by $19.84 \%$, and technical equipment of universities - by $13.99 \%$.

The perspectives of increasing the quality of services of secondary vocational and higher education in Russia's regional economy are connected to transition to the practiceoriented model of education, active use of the network form of education, wide professional and public accreditation of educational programs by employers, and upgrade of equipment by universities. Applied recommendations are offered for this; they are based on expansion of use of the leading technologies according to the federal project of digital education, which is successfully implemented in Russia's regions and is oriented at the period until 2024.

The contribution of the performed research to development of the theory of quality management of education in regional economy consists in the following: firstly, the role of quality in regional economy is specified. Secondly, the factors of formation of quality of secondary vocational and higher education services are determined, and significance of all factors is outlined. Thirdly, the essence, problems, and perspectives of improving the practice of quality management in regional economy are determined.

The scientific \& methodological and practical significance of the results of the performed research consists in the fact that the new - oriented at quality - approach to education management in regional economy clearly reflects the target landmarks of increase of quality of education, allows overcoming all the existing barriers on the path of increase of quality and achievement of the target landmarks, and offers practical recommendations that are available for application by universities of modern Russia. This work's focus on the experience and perspectives of Russia limits its scope, for the authors' conclusions and recommendations have a "narrow" specialization and cannot be applied around the world. Thus, it is recommended to pay more attention during further studied to experience of managing education's quality in the regional economy of other developed and developing countries.

\section{References:}

Alexander, A., \& Manolchev, C. (2020). The future of university or universities of the future: a paradox for uncertain times. International Journal of Educational Management, 34(7),11431153. https://doi.org/10.1108/IJEM-01-2020-0018

Alpidovskaya, M. L., \& Popkova, E. G. (2019). Marx \& Modernity: A Political and Economic Analysis of Social Systems Management. A volume in the series Popkova, E.G. (Ed.) Advances in Research on Russian Business and Management. Charlotte, NC, USA: Information Age Publishing. 
Altınay, F., Altınay, M., Dagli, G., \& Altınay, Z. (2019). A study of knowledge management systems processes and technology in open and distance education institutions in higher education. International Journal of Information and Learning Technology, 36(4), 314321. https://doi.org/10.1108/IJILT-02-2019-0020

Anis, A., \& Islam, R. (2019). Prioritised challenges and critical success factors for delivering quality education in Malaysian private higher education institutions. Quality Assurance in Education, 27(4), 465-492. https://doi.org/10.1108/QAE-11-2018-0122

Ashraf, M. A. (2019). Influences of working condition and faculty retention on quality education in private universities in Bangladesh: An analysis using SEM. International Journal of Educational Management, 33(1), 149-165. https://doi.org/10.1108/IJEM-032018-0121

Bamber, C. J., \& Elezi, E. (2020). What culture is your university? Have universities any right to teach entrepreneurialism? Higher Education Evaluation and Development, 14(1), 1932. https://doi.org/10.1108/HEED-09-2018-0021

Bratukhina, E. A., Lysova, E. A., Lapteva, I. P., Malysheva, N. V. (2020). Marketing management of education quality in the process of university reorganization in industry 4.0: goals of application and new tools. International Journal for Quality Research, 14(2), 369386. https://doi.org/10.24874/IJQR14.02-03.

Duan, S. X. (2019). Measuring university efficiency: An application of data envelopment analysis and strategic group analysis to Australian universities. Benchmarking: An International Journal, 26(4), 1161-1173. https://doi.org/10.1108/BIJ-10-2017-0274

Eldegwy, A., Elsharnouby, T. H., \& Kortam, W. (2018). How sociable is your university brand? An empirical investigation of university social augmenters' brand equity. International Journal of Educational Management, 32(5), 912930. https://doi.org/10.1108/IJEM-12-2017-0346

Federal State Statistics Service (2020). Regions of Russia. Socio-economic indicators - 2018: a statistical collection. Retrieved from: https://www.gks.ru/bgd/regl/b18_14p/Main.htm (data accessed: 04.08.2020).

Felce, A. (2019). Managing the quality of higher education in apprenticeships. Higher Education, Skills and Work-Based Learning, 9(2), 141148. https://doi.org/10.1108/HESWBL-10-2018-0106

Forsyth, H. (2019). The Good University: what Universities Actually do and why it's Time for Radical Change. History of Education Review, 48(1), 133-135. https://doi.org/10.1108/HER06-2019-070

Gerasimova, E. B., Kurashova, A. A., Tipalina, M. V., Bulatenko, M. V., \& Tarasova, N.V. (2019). New state standards of higher education for training of digital personnel in the conditions of Industry 4.0. On the Horizon, 27(3/4), 199-205. https://doi.org/10.1108/OTH07-2019-0043

Gerged, A., \& Elheddad, M. (2020). How can national governance affect education quality in Western Europe? International Journal of Sustainability in Higher Education, 21(3), 413426. https://doi.org/10.1108/IJSHE-10-2019-0314

Goryachikh, S. P., Lapteva, S. V., Matushkina, Y. N., \& Kalinin, P. A. (2019). Audit of training of digital personnel for regional economy in the conditions of Industry 4.0. On the Horizon, 27(3/4), 245-251. https://doi.org/10.1108/OTH-07-2019-0039 
Günay, A., \& Dulupçu, M. A. (2019). Measurement of financial efficiency and productivity of Turkish Public Universities by using non-parametric methods. Journal of Applied Research in Higher Education, 11(4), 876-896. https://doi.org/10.1108/JARHE-07-2018-0116

Hauptman Komotar, M. (2020). Discourses on quality and quality assurance in higher education from the perspective of global university rankings. Quality Assurance in Education, 28(1), 78-88. https://doi.org/10.1108/QAE-05-2019-0055

Inshakova, A. O., \& Bogoviz, A. V. (Ed.) (2020). Alternative Methods of Judging Economic Conflicts in the National Positive and Soft Law. A volume in the series Popkova, E.G. (Ed.) Advances in Research on Russian Business and Management. Charlotte, NC, USA: Information Age Publishing.

Jodoin, J. J. (2020). Promoting language education for sustainable development: a program effects case study in Japanese higher education. International Journal of Sustainability in Higher Education, 21(4), 779-798. https://doi.org/10.1108/IJSHE-09-2019-0258

Kennedy, M., \& Birch, P. (2020). Reflecting on outcome-based education for human services programs in higher education: a policing degree case study. Journal of Criminological Research, Policy and Practice, 26(2), 111-122. https://doi.org/10.1108/JCRPP-12-20190071

Lombardi, R., Massaro, M., Dumay, J., \& Nappo, F. (2019). Entrepreneurial universities and strategy: the case of the University of Bari. Management Decision, 57(12), 33873405. https://doi.org/10.1108/MD-06-2018-0690

Matlay, H. (2018). Entrepreneurship Education: New Perspective on Entrepreneurship Education. Education + Training, 60(7/8), 923-926. https://doi.org/10.1108/ET-08-2018-212

Ministry of Science and Higher Education of the Russian Federation (2020). Information and analytical materials of the monitoring of quality of personnel training - 2019. Retrieved from: http://indicators.miccedu.ru/monitoring/?m=spo (data accessed: 04.08.2020).

National Research University "Higher School of Economics" (2020). Indicators of education 2020: statistical collection. Retrieved from: https://issek.hse.ru/mirror/pubs/share/352549981.pdf (data accessed: 04.08.2020).

Pleśniarska, A. (2019). Monitoring progress in "quality education" in the European Union strategic framework and goals. International Journal of Sustainability in Higher Education, 20(7),1125-1142. https://doi.org/10.1108/IJSHE-10-2018-0171

Popkova E. G., Sozinova A. A., \& Menshchikova V. I. (2019) Managing the Adaptation of Modern Society to the Industry 4.0 Based on Information Waves and Impulses. Voprosy teorii i praktiki zhurnalistiki $=$ Theoretical and Practical Issues of Journalism, 8(2), 438446. doi: 10.17150/2308-6203.2019.8(2). 438-446. (In Russian).

Popkova, E. G. (2017). Economic and Legal Foundations of Modern Russian Society. A volume in the series Popkova, E.G. (Ed.) Advances in Research on Russian Business and Management, Charlotte, NC, USA, Information Age Publishing.

Popkova, E. G. (2019). Preconditions of formation and development of industry 4.0 in the conditions of knowledge economy. Studies in Systems, Decision and Control, 169(1), 65-72.

Popkova, E. G. (2020). A new treatment of quality of goods and services in the conditions of the knowledge economy: opposition of traditions and innovations. International Journal for Quality Research, 14(2), 329-346. https://doi.org/10.24874/IJQR14.02-01.

Popkova, E. G., \& Sergi, B. S. (2020). Human Capital and AI in Industry 4.0. Convergence and Divergence in Social Entrepreneurship in Russia. Journal of Intellectual Capital, https://doi.org/10.1108/JIC-09-2019-0224. 
Popkova, E. G., Przhedetsky, Yu V., Przhedetskaya, N. V., \& Borzenko, K. V. (Ed.) (2020). Marketing of Healthcare Organizations: Technologies of Public-Private Partnership. A volume in the series Popkova, E.G. (Ed.) Advances in Research on Russian Business and Management. Charlotte, NC, USA: Information Age Publishing.

Popkova, E. G., Poluyufta, L., Beshanova, Y., Popova, L. V., \& Kolesnikova, E. (2017). Innovations as a basis for marketing strategies of Russian oil companies in the conditions of oil prices reduction. Contributions to Economics, (9783319606958), 449-455. https://doi.org/10.1007/978-3-319-60696-5_57

Popkova, E. G., \& Sergi, B. S. (2018). Will Industry 4.0 and Other Innovations Impact Russia's Development? In Bruno S. Sergi (Ed.) Exploring the Future of Russia's Economy and Markets: Towards Sustainable Economic Development (pp. 51-68). Bingley, UK: Emerald Publishing Limited.

Popkova, E. G., \& Sergi, B. S. (Eds.) (2019). Digital Economy: Complexity and Variety vs. Rationality. Berlin, Springer International Publishing.

Ragulina, Y. V. (2019). Priorities of development of industry 4.0 in modern economic systems with different progress in formation of knowledge economy. Studies in Systems, Decision \& Control, 169, 167-174.

Rebelatto, B. G., Lange Salvia, A., Reginatto, G., Daneli, R. C., \& Brandli, L. L. (2019). Energy efficiency actions at a Brazilian university and their contribution to sustainable development Goal 7. International Journal of Sustainability in Higher Education, 20(5),842855. https://doi.org/10.1108/IJSHE-01-2019-0023

Roshani, K., Owlia, M. S., \& Abooie, M. H. (2019). A research note on the article of "Quality framework in education through application of interpretive structural modeling". The TQM Journal, 31(1), 3-10. https://doi.org/10.1108/TQM-12-2017-0168

Sahney, S. (2019). A response to "A research note on the article of "Quality framework in education through application of interpretive structural modeling"'. The TQM Journal, 31(1), 11-11. https://doi.org/10.1108/TQM-12-2018-00002

Savelyeva, N. K., Kuklin, A. V., Lapteva, I. P., \& Malysheva, N. V. (2019) The investment attractiveness of a regional market of educational services as the basis of its global competitiveness in industry 4.0. On the Horizon. 27(3-4), 239-244.

Serbina, R. G. (2015). Development of vet quality in Russia in the context of the European model of education quality CQAF. International Journal for Quality Research, 9(2), 323338.

Shahin, A. (2019). Quality and innovation: how to create value for customers by value-added innovation. The TQM Journal, 31(6), 873-873. https://doi.org/10.1108/TQM-11-2019-233

Shulus, A. A., Akopova, E.S., Przhedetskaya, N.V. \& Borzenko, K.V. (2020). Intellectual Production and Consumption: A New Reality of the 21st Century. Lecture Notes in Networks and Systems, 92, 353-359.

Sozinova A. A. (2019) Causal connections of formation of industry 4.0 from the positions of the global economy. Studies in Systems, Decision and Control, 169, 131-134.

Sozinova, A. A. (2018a). Marketing concept of managing the reorganization of entrepreneurial structures using the latest information technologies. Quality-Access to Success, 19. S2. 118122.

Sozinova, A. A. (2018b) Effectiveness or reorganization: Application of information technologies in solving marketing problems of modern companies. Espacios, 39(28), 4. 
Sozinova, A. A., Fokina, O. V., \& Fufacheva, L. A. (2017a) Reorganization of entrepreneurial structures within global crisis management: Problems and perspectives. Overcoming uncertainty of institutional environment as a tool of global crises management. Editors: E.G. Popkova et al. Springer International Publishing AG. P. 3-8.

Sozinova, A. A., Fokina, O. V., \& Shchinova, R. A. (2017b). Marketing tools for increasing

Sozinova, A. A., Nabokikh, A. A., Ryattel, A. V., \& Sanovich, M. A. (2019). Analysis of "underdevelopment whirlpools" as a tool of managing the regional market of education in the conditions of Industry 4.0., 27( 3-4), 173-179.

Stolyarov, N. O., Petrenko, E. S., Serova, O. A., \& Umuralieva, A. S. (2020). The Digital Reality of the Modern Economy: New Actors and New Decision-Making Logic. Lecture Notes in Networks and Systems, 87, 882-888.

Vijay, A. (2013). Appraisal of student rating as a measure to manage the quality of higher education in India: an institutional study using six sigma model approach. International Journal for Quality Research, 7(3), 3-14.

Watson, K., \& McGowan, P. (2019). Rethinking competition-based entrepreneurship education in higher education institutions: Towards an effectuation-informed coopetition model. Education + Training, 62(1), 31-46. https://doi.org/10.1108/ET-11-2018-0234

Wilson, E. (2019). Is feedback to tutors the key to supporting quality in adult education? A case study of a private training organisation in New Zealand. Quality Assurance in Education, 27(3), 338-346. https://doi.org/10.1108/QAE-11-2017-0072

Wright, E., \& Horta, H. (2018). Higher education participation in "high-income" universal higher education systems: "Survivalism" in the risk society. Asian Education and Development Studies, 7(2), 184-204. https://doi.org/10.1108/AEDS-07-2017-0061

Andrey V. Kuklin

Vyatka State University and Vyatka State Agricultural Academy, Kirov, Russia avkuklin@vyatsu.ru
Elena A. Bratukhina

Vyatka State University, Kirov,

Russia

ea_bratuhina@vyatsu.ru
Yulia O.

Gorokhovitskaya

Samara State University of

Economics (Syzran branch),

Russia

gorohovickaya@bk.ru 